\title{
Economic and efficiency analysis of beekeeping activity in Turkey: Case of Çanakkale Province
}

\author{
Başak AYDIN ${ }^{1, a, 凶}$, Duygu AKTÜRK ${ }^{2, b}$, Dilek ARSOY ${ }^{3, c}$ \\ ${ }^{1}$ Atatürk Soil, Water and Agricultural Meteorology Research Institute, Kırklareli, Turkey; ${ }^{2}$ Çanakkale 18 Mart University, Faculty \\ of Agriculture, Department of Agricultural Economics, Çanakkale, Turkey; ${ }^{3}$ Near East University, Veterinary Medicine Faculty, \\ Department of Animal Science, Nicosia, Northern Cyprus.

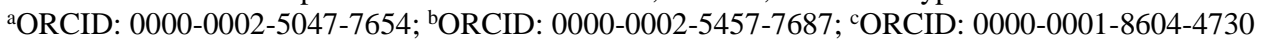

$\triangle$ Corresponding author: basakaydin_1974@yahoo.com

Received date: 29.05.2019- Accepted date: 20.09.2019

\begin{abstract}
This study was carried out to determine the economic structure and efficiencies of the beekeeping enterprises in Çanakkale Province. Beekeepers were divided into three groups/strata according to number of hives: 1-75 hives (first group), 76-150 hives (second group) and 151 hives and above (third group). Survey sample size was determined as 87 based on stratified random sampling method. The portion of fixed costs were $65.25 \%$ and variable costs were $34.75 \%$ in averages of production costs of all enterprises. The cost of honey production per kg changed between 2.04 US\$ to 3.54 US\$ among to enterprises. The average production cost of honey per kg was 2.92 US\$. Average yield amount per hive was $16.24 \mathrm{~kg}$ and production cost per hive was 53.32 US\$. Besides, average gross profit, net profit and relative profit were determined as 77.53 US\$, 42.74 US\$ and 1.80, respectively. According to the average of the enterprises, total technical efficiency (constant return to scale), pure technical efficiency (variable return to scale), scale efficiency, allocative efficiency and economic efficiency were found as $0.64,0.89,0.70,0.74$ and 0.66 , respectively. It was determined that producer's age and agricultural activity apart from beekeeping affected the economic efficiency negatively and land size, income per hive and honeycomb changing frequency affected the economic efficiency positively. According to the results, it was concluded that honey production was a profitable activity in Çanakkale Province and relative profits and efficiencies of the enterprises in the third group were higher than the other groups.
\end{abstract}

Keywords: Beekeeping, cost, efficiency, honey, profitability.

\section{Türkiye'de arıcılık faaliyetinin ekonomik ve etkinlik analizi: Çanakkale ili örneği}

Özet: Bu çalışma Çanakkale ilinde faaliyet gösteren arıcılık işletmelerinin ekonomik yapısının ve etkinliklerinin belirlenmesi amacıyla yapılmıştır. İşletmeler kovan sayılarına göre üç gruba/tabakaya ayrılmıştır: 1-75 kovan (birinci grup), 76-150 kovan (ikinci grup) ve 151 kovan ve üzeri (üçüncü grup). Tabakalı tesadüfi örnekleme yöntemine göre örnek büyüklüğü 87 olarak belirlenmiştir. İşletmeler ortalamasına göre üretim masraflarının \%34,75'i değişken masraflardan, \%65,25'i sabit masraflardan oluşmaktadır. İşletmelerde $1 \mathrm{~kg}$ balın maliyeti 2,04 US\$ ile 3,54 US\$ arasında değişmektedir. Ortalama bal maliyeti 2,92 US\$'dir. Ortalama kovan başına verim 16,24 kg, kovan başına üretim masrafı 53,32 US\$'dır. Ortalama brüt kâr 77,53 US\$, net kâr 42,74 US\$, nispi kâr ise 1,80 olarak belirlenmiştir. İşletmeler ortalamasına göre toplam teknik etkinlik (ölçeğe sabit getiri) 0,64, saf teknik etkinlik (ölçeğe değişken getiri) 0,89 , ölçek etkinliği 0,70 , kaynak dağıtım etkinliği 0,74 , ekonomik etkinlik 0,66 olarak bulunmuştur. İşletme sahibinin yaşının ve tarımda arıcılık dışı faaliyetle uğraşma durumunun ekonomik etkinliği negatif, arazi büyüklüğünün, kovan başına elde edilen gelirin ve petek değiştirme sıklı̆̆ının pozitif yönde etkilediği belirlenmiştir. Bu sonuçlardan hareketle, Çanakkale ilinde gerçekleştirilen bal üretiminin kârlı bir üretim faaliyeti olduğu, ancak üçüncü gruptaki işletmelerin nispi kârlarının ve etkinliklerinin diğer gruplara göre daha yüksek olduğunu söylemek mümkündür.

Anahtar sözcükler: Arıcılık, bal, etkinlik, kârlılık, maliyet.

\section{Introduction}

Beekeeping is a producing activity of living substances such as queen and drone and products such as honey, beeswax, pollen, royal jelly, bee gum and bee venom by using herbal sources, bee and labor together (24). Beekeeping is dependent on nature due to the lifestyle of the honey bees and the collection of the raw materials of the products from nature (27). Beekeeping has a significant role in rural development in many countries in the world and Turkey (21).

In 2018, there were approximately 91 million beehives in the world, and the produced honey amount was 1.8 million tons (5). The average honey yield per hive in the world was $22 \mathrm{~kg}$ and this value was $50-51 \mathrm{~kg}$ in 
China, $39 \mathrm{~kg}$ in Mexico, 26-27 kg in Argentina and $26 \mathrm{~kg}$ in the USA. Honey production per hive was $14.6 \mathrm{~kg}$ in Turkey and it was ranked at the twelfth in the world. Turkey takes third place in terms of total hive number and takes second place in terms of total production amount (14).

Turkey contains $20 \%$ of the bee races in the world (8). Turkey has $75 \%$ of world honeyed plant flora. Turkey has a great beekeeping potential in terms of rich flora, suitable ecology, colony existence and genetic variation in bee population (29). According to the data of 2017, total number of the hives, honey production, beeswax production and total number of the enterprises were 7991072,114 471 tons, 4488 tons and 83 210, respectively (31).

As in Turkey, beekeeping activity, which can be done with little capital and expense by not being dependent on an area, has been a significant side income source in Çanakkale Province. Çanakkale is an appropriate nutrition area for the bees in terms of plant species and variety (18). Blossom honey is produced in the province predominantly besides the honeydew honey production. According to the data of 2018, total number of the hives was 79635 and 1689 tons of honey was produced (14). Biga, Central, Çan and Yenice districts come into prominence in beekeeping activities. Organic beekeeping activities are conducted in Gökçeada and Ezine districts (6).

The aim of this study was to determine the economic structure of beekeeping activity in Çanakkale Province. Honey costs of the beekeeping enterprises were calculated, the incomes and the expenses were examined and the profitability of beekeeping activity was introduced. Besides, efficiency analysis (technical efficiency, allocative efficiency and economic efficiency) at enterprise level was done and some effective socio economic factors of economic efficiency were analyzed.

\section{Material and Methods}

The material of the study was the survey data which were collected from the beekeepers who were registered to Çanakkale Beekeepers Union. Besides, it was utilized from the local and foreign studies related to the research subject and the statistics.

The data concerning the number of the hives of the beekeepers were obtained from Çanakkale Beekeepers Union. The beekeepers who have the number of 30 and above hives are affiliated to beekeepers unions. It was determined from the data that there were 368 registered beekeepers to Çanakkale Beekeepers Union in 2018. As the variation coefficient was high, stratified sampling was done. In stratified random sampling method, the following formulas were used (13).

$$
=\frac{\mathrm{N} \sum\left[\mathrm{N}_{\mathrm{h}}\left(\mathrm{S}_{\mathrm{h}}\right)^{2}\right]}{\mathrm{N}^{2} \mathrm{D}^{2}+\sum \mathrm{N}_{\mathrm{h}}\left(\mathrm{S}_{\mathrm{h}}\right)^{2}} \text { and } n_{i}=\frac{\mathrm{N}_{\mathrm{h}}}{\sum \mathrm{N}_{\mathrm{h}}} * \mathrm{n}
$$

$D^{2}=(d / Z)^{2}, d=$ deviation from average , $Z=$ degree of freedom, $\mathrm{N}_{\mathrm{h}}=$ number of the enterprises in the strata, $\mathrm{S}_{\mathrm{h}}=$ Standard deviation of the strata, $\mathrm{S}_{\mathrm{h}}{ }^{2}=$ Variance of the strata, $n_{1}=$ sample number in the strata $n=$ sample size

The number of the beekeepers were divided into three strata, including 1-75 hives (first group), 76-150 hives (second group) and 151 hives and above (third group). The number of the surveyed beekeepers was determined as 87 with 5\% sampling error margin and in $95 \%$ confidence interval. The surveyed beekeepers were distributed to the strata proportionately (32). There were 27 surveyed beekeepers in the first group, 38 surveyed beekeepers in the second group and 22 surveyed beekeepers in the third group.

It was utilized from some descriptive analysis such as average, standard deviation, and percentages, statistics, parametric and non-parametric tests for the evaluation of the data. The convenience of the continuous data to normal distribution was determined by Kolmogorov-Smirnov test. Variance analysis was used for normally distributed continuous data, Kruskal Wallis test was used for nonnormally distributed continuous data and Chi-square test was used for discrete data in order to determine the differences between the groups.

Man labor unit was used for the determination of the labor potential used in the production. Man labor unit is the labor that an adult male employee (15-49 ages) reveals by working average 10 hours in a day and 300 days in a year (7).

The amortization ratio for the calculation of devicemachine amortization was taken as $10 \%$ (24). When calculating the device-machine and bee capital interest compensations, Ziraat Bank real interest rate $(6 \%)$ was applied to half of the device-machine and bee capital value (20). General administration expenses was calculated by taking $3 \%$ of the total variable costs. The wage level paid to alien labor was taken in exchange for the family labor fee.

Feed (sugar) costs, drug costs, honeycomb costs, fuel-transport costs, jar-tin costs, accommodation costs, temporary labor costs, repair and maintenance costs and circulating capital interest were taken as variable costs. General administration expenses, family labor fee, bee capital interest, device-machine amortization, devicemachine capital interest, subscription and insurance fee were taken as fixed costs.

Circulating capital interest was calculated by applying 6\% (the agricultural credit interest rate applied by Ziraat Bank) to half of the variable costs. For the calculation of the production cost of one $\mathrm{kg}$ of honey, byproduct (beeswax, pollen, bee gum) income is subtracted from total production costs and this value is divided to total honey amount (3). Gross output value is calculated by the addition of the honey income and byproduct income. Gross profit is found by subtracting the 
variable costs from gross output value. Net profit is found by subtracting the production costs from gross output value. Relative profit is found by dividing the gross output value to the production costs.

Data envelopment analysis was used for the efficiency analysis. In data envelopment analysis, the unit which obtains the maximum output with minimum input is determined and an efficient frontier is composed with these units. The efficiencies of the other decision-making units are determined by measuring the radial distances to this frontier.

The achievement of the enterprise on producing the maximum output by using the input combination properly is named as technical efficiency. Allocative efficiency is the achievement of selecting the input combination which will minimize the production cost by considering the input and output prices of the enterprise. Price information is not required in technical efficiency but allocative efficiency is calculated over this information. Economic efficiency is obtained by the combination of technical efficiency and allocative efficiency (30).

Technical efficiency that shows whether enterprises operate effectively or not is divided into two subgroups as pure technical efficiency and scale efficiency (11).

Pure technical efficiency indicates the efficient usage of the inputs according to variable return to scale assumption. If technical efficiency values for constant return to scale and variable return to scale are different for a specific production unit, this indicates that the production unit has scale inefficiency. Accordingly, scale efficiency could be explained in this way (33).
Technical efficiency (CRS) $=$ Pure technical efficiency (VRS) x Scale efficiency

In the efficiency analysis, enterprises with efficiency coefficient between 0.95 and 1 are considered as effective, between 0.90 and 0.95 are considered as less effective and less than 0.90 are classified as ineffective enterprises (10). Since producers have more tendency to control their inputs than their outputs, efficiency measurements of Farrell (15) relating to inputs was used in this study. DEAP 2.1 statistical package program was used for the estimation of the efficiency measurements.

Total income was accepted as output and labor, variable costs, fixed costs and number of frame were accepted as inputs in the model. A model was designed with four inputs and one output. The relations between the efficiency scores and demographic, economic and social characteristics was put forward by Tobit model. Tobit model was developed by James Tobin, and also named as censored or discrete regression model (16). EViews 4 program was used for the estimation of Tobit model.

\section{Results}

Economic analysis: The average variable costs, fixed costs and total production costs per hive were found at 18.53 US\$, 34.79 US\$ and 53.32 US\$, respectively. According to Kruskal Wallis test, feed, drug, honeycomb, jar-tin, temporary labor expenses, bee capital interest, device-machine amortization, device-machine capital interest, union subscription, total fixed costs and total production costs changed according to the enterprise size groups (Table 1).

Table 1. Variable, fixed and total costs of beekeeping in the enterprises (US\$/hive).

\begin{tabular}{lccccc}
\hline \multirow{2}{*}{ Cost items } & \multicolumn{3}{c}{ Enterprise groups } & \multirow{2}{*}{ Average } & P \\
\cline { 2 - 4 } & First group & Second group & Third group & & 18.53 \\
\hline Variable costs & 17.52 & 18.55 & 19.74 & 0.916 \\
Feed (sugar) costs & 2.28 & 4.66 & 5.49 & 4.13 & $0.038^{* *}$ \\
Drug costs & 2.89 & 1.76 & 2.38 & 2.27 & $0.010^{*}$ \\
Honeycomb costs & 3.44 & 2.06 & 2.76 & 2.67 & $0.035^{* *}$ \\
Fuel-transport costs & 5.46 & 6.87 & 5.24 & 6.02 & 0.116 \\
Jar-tin costs & 1.66 & 1.15 & 1.63 & 1.43 & $0.047^{* *}$ \\
Accommodation costs & 0.47 & 0.41 & 0.36 & 0.42 & 0.571 \\
Temporary labor costs & 0.07 & 0.70 & 0.83 & 0.54 & $0.082^{*}$ \\
Repair and maintenance costs & 0.73 & 0.40 & 0.47 & 0.52 & 0.868 \\
Circulating capital interest & 0.51 & 0.54 & 0.57 & 0.54 & 0.912 \\
\hline Fixed costs & 46.10 & 31.81 & 26.07 & 34.79 & $0.004^{* * *}$ \\
General administration expenses & 0.53 & 0.56 & 0.59 & 0.56 & 0.910 \\
Family labor fee & 33.90 & 25.68 & 22.09 & 27.32 & 0.274 \\
Bee capital interest & 6.98 & 2.47 & 1.35 & 3.59 & $0.000^{* * *}$ \\
Device-machine amortization & 2.64 & 1.74 & 1.17 & 1.87 & $0.001^{* * *}$ \\
Device-machine capital interest & 1.15 & 0.72 & 0.52 & 0.80 & $0.002^{* * *}$ \\
Subscription & 0.42 & 0.18 & 0.11 & 0.24 & $0.000^{* * *}$ \\
Insurance fee & 0.48 & 0.47 & 0.24 & 0.41 & 0.930 \\
Total production costs & 63.62 & 50.36 & 45.81 & 53.32 & $0.057^{*}$ \\
\hline
\end{tabular}

*: Significant at $10 \%$ significance level; **: Significant at 5\% significance level; ***: Significant at $1 \%$ significance level; 1 US\$ $=4.813$ TL in 2018 (average). 
According to the average of the enterprises, it was determined that $34.75 \%$ of the total production costs were variable costs whereas $65.25 \%$ was fixed costs. The ratio of variable and fixed costs in total production costs changed according to the groups. Fuel-transport costs had the highest ratio $(11.29 \%)$ in the variable costs and this was due to the migratory beekeeping. The ratios of feed (sugar) costs and honeycomb costs were $7.74 \%$ and $5.00 \%$, respectively. Family labor fee had a significant ratio with $51.24 \%$ in total production costs (Table 2).

According to the average of the enterprises, honey production amount per hive was found as $16.24 \mathrm{~kg}$ and this value increased according to the enterprise size groups. The income obtained from honey production was found as 90.23 US\$ according to the average of the enterprises (Table 3). In the enterprises, besides the honey production, the production of the byproducts such as royal jelly, beeswax, pollen and bee gum, was carried out. However, as the amount of these products was low, it was determined that the producers preferred to evaluate the bee gum in their enterprises and sell royal jelly, beeswax and pollen to various markets. From this viewpoint, it is expected that the increase of the amounts of byproducts affects the operating profits of the enterprises positively.

Table 2. Ratio of the costs items in total production costs $(\%)$.

\begin{tabular}{lcccc}
\hline \multirow{2}{*}{ Cost items } & \multicolumn{3}{c}{ Enterprise groups } & Average \\
\cline { 2 - 4 } & First group & Second group & Third group & 34.75 \\
Variable costs & 27.54 & 36.8 & 43.09 & 7.74 \\
Feed (sugar) costs & 3.58 & 9.25 & 11.99 & 4.26 \\
Drug costs & 4.54 & 3.50 & 5.20 & 5.00 \\
Honeycomb costs & 5.41 & 4.10 & 6.03 & 11.29 \\
Fuel-transport costs & 8.59 & 13.64 & 11.45 & 2.68 \\
Jar-tin costs & 2.61 & 2.28 & 3.55 & 0.78 \\
Accommodation costs & 0.74 & 0.81 & 0.78 & 1.01 \\
Temporary labor costs & 0.10 & 1.39 & 1.81 & 0.98 \\
Repair and maintenance costs & 1.15 & 0.80 & 1.03 & 1.25 \\
Circulating capital interest & 0.80 & 1.07 & 56.91 & 1.29 \\
Fixed costs & 72.46 & 63.16 & 48.22 & 65.25 \\
General administration expenses & 0.83 & 1.11 & 2.96 & 1.04 \\
Family labor fee & 53.29 & 50.99 & 2.54 & 51.24 \\
Bee capital interest & 10.98 & 4.91 & 1.13 & 6.73 \\
Device-machine amortization & 4.15 & 3.45 & 0.24 & 3.51 \\
Device-machine capital interest & 1.80 & 1.42 & 0.52 & 1.50 \\
Subscription & 0.66 & 0.36 & 100.00 & 0.45 \\
Insurance fee & 0.75 & 0.92 & & 0.77 \\
Total production costs & 100.00 & 100.00 & & 100.00 \\
\hline
\end{tabular}

Table 3. Economic analysis results.

\begin{tabular}{|c|c|c|c|c|c|}
\hline \multirow{2}{*}{ Profitability indicators } & \multicolumn{3}{|c|}{ Enterprise groups } & \multirow{2}{*}{ Average } & \multirow{2}{*}{$\mathbf{P}$} \\
\hline & First group & Second group & Third group & & \\
\hline Honey production amount (kg/hive) & 15.78 & 14.98 & 18.97 & 16.24 & 0.120 \\
\hline Honey production value & 88.26 & 82.77 & 105.54 & 90.23 & 0.132 \\
\hline $\begin{array}{l}\text { Bee products production value (beeswax, pollen, } \\
\text { bee gum, royal jelly) }\end{array}$ & 7.81 & 3.73 & 7.02 & 5.83 & 0.443 \\
\hline Gross output value & 96.07 & 86.50 & 112.56 & 96.06 & $0.074^{*}$ \\
\hline Variable costs (US\$/hive) & 17.52 & 18.55 & 19.74 & 18.53 & 0.916 \\
\hline Fixed costs (US\$/hive) & 46.10 & 31.81 & 26.07 & 34.79 & $0.004 * * *$ \\
\hline Production costs (US\$/hive) & 63.62 & 50.36 & 45.81 & 53.32 & $0.057 *$ \\
\hline Production cost of $1 \mathrm{~kg}$ of honey & 3.54 & 3.11 & 2.04 & 2.92 & 0.104 \\
\hline Gross profit & 78.55 & 67.95 & 92.82 & 77.53 & $0.068^{*}$ \\
\hline Net profit & 32.45 & 36.14 & 66.75 & 42.74 & $0.027 * *$ \\
\hline Relative profit & 1.51 & 1.72 & 2.46 & 1.80 & $0.013 * *$ \\
\hline
\end{tabular}

*: Significant at $10 \%$ significance level; **: Significant at $5 \%$ significance level; ***: Significant at $1 \%$ significance level; $1 \mathrm{US} \$=4.813 \mathrm{TL}$ in 2018 (average). 
The average production cost of one $\mathrm{kg}$ of honey was calculated as 2.92 US\$. In terms of the enterprise size groups, the production cost of one $\mathrm{kg}$ of honey was found as 3.54 US\$ in the first group, 3.11 US\$ in the second group and 2.04 US\$ in the third group. According to these results, it was determined that the honey cost had the highest value in the first group.

Gross profit is accepted as a significant success criterion on the determination of the competitive power of the production activities (19). According to the average of the enterprises, gross output value and gross profit were found as $96.06 \mathrm{US} \$ /$ hive and 77.53 US\$/hive. The ratio of the gross profit in gross output value was determined as $80.71 \%$. The net profit, indicating the investment and administration income, was found as 42.74 US\$/hive and the ratio of the net profit in gross output value was found as $47.37 \%$. When the net profit values were examined in terms of enterprise size groups, it was concluded that the net profit value increased due to the increase of the hive number. It was determined that the enterprises in the third group obtained more net profit according to the enterprises in the first and second groups.

It is accepted that the relative profit is a preferable criterion for the producers on the investments of a production activity. The average relative profit was found as 1.80 in the enterprises. This value indicated that 1.80 US\$ profit was obtained for 1 US\$ of expense for honey production in the enterprises. In terms of enterprise size groups, the relative profit value was determined as 1.51 in the first group, 1.72 in the second group and 2.46 in the third group. According to these results, it can be said that the enterprises in the third group were more advantageous than the other enterprises.

According to Kruskal Wallis test, it was determined that there were statistically differences $(\mathrm{P}<0.05)$ between the groups in terms of gross output value, total fixed costs, total production costs, gross profit, net profit and relative profit (Table 3).

Efficiency analysis: According to the average of the enterprises, total technical efficiency (constant return to scale) was found as 0.64 and pure technical efficiency (variable return to scale) was found as 0.89 . This value indicated that the inefficient enterprises could reduce the inputs in the ratio of $11 \%$ by not decreasing the outputs. Pure technical efficiency values were found as $0.84,0.89$ and 0.94, respectively by the groups (Table 4). Accordingly, it can be said that the enterprises in the third group were more efficient than the enterprises in the first and second groups, technically.

Technical inefficiency is generally based on two main factors; operating with inappropriate input combination and operating in inappropriate scale. According to the data envelopment results, average scale efficiency was found as 0.70 . This indicated that technical inefficiency was generally based on operating in inappropriate scale.

The enterprises were classified according to the technical efficiency. Accordingly, it was determined that $48.15 \%$ of the enterprises in the first group, $50 \%$ of the enterprises in the second group and $63.64 \%$ of the enterprises in the third group were technically efficient (Table 5). Chi-square test results indicated that the technical efficiency changed according to the groups $(\mathrm{P}=0.017)$.

Table 4. Descriptive statistics of technical efficiency scores.

\begin{tabular}{lcccccccccccc}
\hline \multirow{2}{*}{ Efficiency level } & \multicolumn{3}{c}{ First group } & \multicolumn{4}{c}{ Second group } & \multicolumn{3}{c}{ Third group } & \multicolumn{3}{c}{ Average } \\
\cline { 2 - 14 } & CRS & VRS & SE & CRS & VRS & SE & CRS & VRS & SE & CRS & VRS & SE \\
\hline Minimum & 0.17 & 0.50 & 0.18 & 0.20 & 0.61 & 0.26 & 0.24 & 0.70 & 0.26 & 0.17 & 0.50 & 0.18 \\
Maximum & 1.00 & 1.00 & 1.00 & 1.00 & 1.00 & 1.00 & 1.00 & 1.00 & 1.00 & 1.00 & 1.00 & 1.00 \\
Average & 0.53 & 0.84 & 0.61 & 0.64 & 0.89 & 0.70 & 0.78 & 0.94 & 0.83 & 0.64 & 0.89 & 0.70 \\
Standard deviation & 0.30 & 0.18 & 0.27 & 0.26 & 0.12 & 0.24 & 0.23 & 0.10 & 0.22 & 0.28 & 0.14 & 0.26 \\
\hline
\end{tabular}

CRS: Total technical efficiency (constant return to scale); VRS: Pure technical efficiency (variable return to scale); SE: Scale efficiency.

Table 5. Classification of the enterprises according to the technical efficiency scores.

\begin{tabular}{lcccccccc}
\hline \multirow{2}{*}{ Efficiency status } & \multicolumn{2}{c}{ First group } & \multicolumn{2}{c}{ Second group } & \multicolumn{2}{c}{ Third group } & \multicolumn{2}{c}{ Total } \\
\cline { 2 - 9 } & Number & \% & Number & \% & Number & \% & Number & \% \\
\hline Efficient $(0.95 \leq \mathrm{TE} \leq 1)$ & 13 & 48.15 & 19 & 50.00 & 14 & 63.64 & 46 & 52.87 \\
Less efficient $(0.90 \leq \mathrm{TE} \leq 0.949)$ & 2 & 7.41 & 0 & 0.00 & 4 & 18.18 & 6 & 6.90 \\
Inefficient $(\mathrm{TE} \leq 0.899)$ & 12 & 44.44 & 19 & 50.00 & 4 & 18.18 & 35 & 40.23 \\
Total & 27 & 100.00 & 38 & 100.00 & 22 & 100.00 & 87 & 100.00 \\
$\mathrm{P}=0.017$ & & & & & & & & \\
\hline
\end{tabular}


According to the average of the enterprises, $77.01 \%$ of the enterprises had increasing return to scale, $18.39 \%$ of the enterprises had constant return to scale and $4.60 \%$ of the enterprises had decreasing return to scale (Table 6). It was concluded that the ratio of constant return to scale index in the third group was higher than the other groups. Chi-square test results indicated that returns to scale did not change according to the groups.

Allocative efficiency values changed between 0.31 and 1 by the groups and it was found as 0.74 on the average (Table 7). This value indicated that a great majority of the beekeepers made production with improper input combination in current technology level when the current input prices were taken into consideration. The enterprises made expenses in the ratio of $26 \%$ more than the input combination with minimum costs. Allocative efficiency coefficients differed by enterprise size groups $(\mathrm{F}=4.166, \mathrm{P}=0.019)$.

The enterprises were classified according to the allocative efficiency. According to the average of the enterprises, it was determined that $20.69 \%$ of the producers allocated the sources efficient and this value was found as $14.81 \%$ in the first group, $13.16 \%$ in the second group and $40.91 \%$ in the third group (Table 8). Chi-square test results indicated that the allocative efficiency changed according to the groups $(\mathrm{P}=0.018)$.

Table 6. Returns to scale by enterprise land sizes.

\begin{tabular}{lcccccccc}
\hline \multirow{2}{*}{ Return to scale } & \multicolumn{2}{c}{ First group } & \multicolumn{2}{c}{ Second group } & \multicolumn{2}{c}{ Third group } & \multicolumn{2}{c}{ Total } \\
\cline { 2 - 9 } & Number & \% & Number & \% & Number & \% & Number & \% \\
\cline { 2 - 9 } Increasing returns to scale & 21 & 77.78 & 31 & 81.58 & 15 & 68.18 & 67 & 77.01 \\
Constant returns to scale & 5 & 18.52 & 5 & 13.16 & 6 & 27.27 & 16 & 18.39 \\
Decreasing returns to scale & 1 & 3.70 & 2 & 5.26 & 1 & 4.55 & 4 & 4.60 \\
Total & 27 & 100.00 & 38 & 100.00 & 22 & 100.00 & 87 & 100.00 \\
P=0.728 & & & & & & & & \\
\hline
\end{tabular}

Table 7. Descriptive statistics of allocative efficiency scores.

\begin{tabular}{lcccc}
\hline Groups & Average & Standard deviation & Minimum & Maximum \\
\hline First group & $0.66^{\mathrm{a}}$ & 0.21 & 0.35 & 1.00 \\
Second group & $0.76^{\mathrm{b}}$ & 0.16 & 0.42 & 1.00 \\
Third group & $0.81^{\mathrm{b}}$ & 0.20 & 0.31 & 1.00 \\
Average & 0.74 & 0.20 & 0.31 & 1.00 \\
\hline
\end{tabular}

a, b. Values within a column with different superscripts differ significantly at $\mathrm{P}<0.05$.

Table 8. Classification of the enterprises according to allocative efficiency scores.

\begin{tabular}{lcccccccc}
\hline \multirow{2}{*}{ Efficiency status } & \multicolumn{2}{c}{ First group } & \multicolumn{2}{c}{ Second group } & \multicolumn{2}{c}{ Third group } & \multicolumn{2}{c}{ Total } \\
\cline { 2 - 9 } & Number & \% & Number & \% & Number & \% & Number & \% \\
\hline Efficient $(0.95 \leq \mathrm{TE} \leq 1)$ & 4 & 14.81 & 5 & 13.16 & 9 & 40.91 & 18 & 20.69 \\
Less efficient $(0.90 \leq \mathrm{TE} \leq 0.949)$ & 2 & 7.41 & 1 & 2.63 & 3 & 13.64 & 6 & 6.90 \\
Inefficient $(\mathrm{TE} \leq 0.899)$ & 21 & 77.78 & 32 & 84.21 & 10 & 45.45 & 63 & 72.41 \\
Total & 27 & 100.00 & 38 & 100.00 & 22 & 100.00 & 87 & 100.00 \\
$\mathrm{P}=0.018$ & & & & & & & &
\end{tabular}

According to the average of the enterprises, it was determined that the economic efficiency changed between 0.21 and 1 and it was found as 0.66 on average. This value meant that the inefficient enterprises should reduce the operation expenses in the ratio of $34 \%$ in order to reach the level of the efficient enterprises. Economic efficiency values were found as $0.56,0.68$ and 0.77 , respectively by the groups (Table 9). Accordingly, it can be said that the enterprises in the third group operated economically more efficient than the enterprises in the first and second groups.
Economic efficiency coefficients differed by enterprise size groups $(\mathrm{F}=5.585, \mathrm{P}=0.005)$.

The enterprises were classified according to the economic efficiency. According to the average of the enterprises, it was determined that $14.81 \%$ of the enterprises in the first group, $13.16 \%$ of the enterprises in the second group and $27.27 \%$ of the enterprises in the third group were economically efficient and this value was found as $17.27 \%$ according to the average of the enterprises (Table 10). Chi-square test results indicated 
that the economic efficiency changed according to the groups $(\mathrm{P}=0.008)$.

Effect of some factors on economic efficiency: The effect of some factors on economic efficiency was determined. Average, standard deviation, minimum and maximum values of the variables used in Tobit model are given in Table 11.

The average age, education period, family size, beekeeping experiences of the producers were found as 54.71 years, 9.28 years 3.02 persons and 19.37 years, respectively. The average land size was 13.94 da. The average income per hive was 96.96 US\$ whereas the nonagricultural income per hive was 3535.06 US\$. Performing an agricultural activity apart from keeping was very low whereas migratory keeping was quite prevalent. Honeycomb changing frequency was found as 2.69 years.

The education periods, family sizes, nonagricultural incomes of the beekeepers and migratory keeping were determined to have negative effects and experience of the beekeepers was determined to have positive effects on economic efficiency. These variables were not statistically significant $(\mathrm{P}>0.10)$.

Producer's age affected the economic efficiency negatively $(\mathrm{P}=0.0490)$. As the ages of the producers increased, the economic efficiency decreased. This can be explained that as the education levels of the young producers increased, they were more interested in the innovations and by this way, they could obtain more yield and accordingly more income.

Table 9. Descriptive statistics of economic efficiency scores.

\begin{tabular}{lcccc}
\hline Enterprise size groups & Average & Standard deviation & Minimum & Maximum \\
\hline First group & $0.56^{\mathrm{a}}$ & 0.25 & 0.21 & 1.00 \\
Second group & $0.68^{\mathrm{b}}$ & 0.19 & 0.33 & 1.00 \\
Third group & $0.77^{\mathrm{b}}$ & 0.22 & 0.31 & 1.00 \\
Average & 0.66 & 0.23 & 0.21 & 1.00 \\
\hline
\end{tabular}

a, b: Values within a column with different superscripts differ significantly at $\mathrm{P}<0.05$.

Table 10. Classification of the enterprises according to economic efficiency scores.

\begin{tabular}{lcccccccc}
\hline \multirow{2}{*}{ Efficiency status } & \multicolumn{2}{c}{ First group } & \multicolumn{2}{c}{ Second group } & \multicolumn{2}{c}{ Third group } & \multicolumn{2}{c}{ Total } \\
\cline { 2 - 9 } & Number & \% & Number & \% & Number & \% & Number & \% \\
\hline Efficient $(0.95 \leq \mathrm{TE} \leq 1)$ & 4 & 14.81 & 5 & 13.16 & 6 & 27.27 & 15 & 17.24 \\
Less efficient $(0.90 \leq \mathrm{TE} \leq 0.949)$ & 2 & 7.41 & 0 & 0.00 & 5 & 22.73 & 7 & 8.05 \\
Inefficient $(\mathrm{TE} \leq 0.899)$ & 21 & 77.78 & 33 & 86.84 & 11 & 50.00 & 65 & 74.71 \\
Total & 27 & 100.00 & 38 & 100.00 & 22 & 100.00 & 87 & 100.00 \\
$\mathrm{P}=0.008$ & & & & & & & & \\
\hline
\end{tabular}

Table 11. Descriptive statistics of the variables used in Tobit model.

\begin{tabular}{|c|c|c|c|c|}
\hline Variables & Average* & Standard deviation & Minimum & Maximum \\
\hline \multicolumn{5}{|l|}{ Demographic characteristics } \\
\hline Producer's age (year) & 54.71 & 1.64 & 30.00 & 80.00 \\
\hline Education period (year) & 9.28 & 4.04 & 5.00 & 15.00 \\
\hline Family size (person) & 3.02 & 0.99 & 2.00 & 5.00 \\
\hline Beekeeping experience (year) & 19.37 & 9.91 & 3.00 & 48.00 \\
\hline \multicolumn{5}{|l|}{ General characteristics of the enterprise } \\
\hline Land size (da) & 13.94 & 27.10 & 0.00 & 175.00 \\
\hline Income per hive (US\$) & 96.06 & 48.19 & 25.15 & 237.90 \\
\hline $\begin{array}{l}\text { Dealing with an agricultural activity apart from } \\
\text { beekeeping }\end{array}$ & 0.21 & 0.41 & 0.00 & 1.00 \\
\hline Nonagricultural income (US\$) & 3535.06 & 1977.67 & 0.00 & 12466.24 \\
\hline \multicolumn{5}{|l|}{ Beekeeping activities } \\
\hline Migratory beekeeping & 0.87 & 0.33 & 0.00 & 1.00 \\
\hline Honeycomb changing frequency (year) & 2.69 & 0.78 & 1.00 & 5.00 \\
\hline
\end{tabular}

*: Arithmetic mean was used in distance and ratio data as measure of central tendency. 
Table 12. Tobit analysis results: Factors affecting the economic efficiency.

\begin{tabular}{lccc}
\hline Variables & Coefficient & Standard error & P \\
\hline Producer's age & $-0.005937^{* *}$ & 0.003016 & 0.0490 \\
Education period & -0.009026 & 0.006517 & 0.1660 \\
Family size & -0.008608 & 0.026548 & 0.7457 \\
Beekeeping experience & 0.002494 & 0.002773 & 0.3684 \\
Land size & $0.001672^{*}$ & 0.000871 & 0.0549 \\
Income per hive & $0.000369^{* * *}$ & 0.000101 & 0.0002 \\
Agricultural activity apart from beekeeping 1 & $-0.092220^{*}$ & 0.055445 & 0.0963 \\
Nonagricultural income & -0.00000001 & 0.000000027 & 0.4730 \\
Migratory beekeeping ${ }^{2}$ & -0.045193 & 0.068585 & 0.5099 \\
Honeycomb changing frequency & $0.055705^{* *}$ & 0.027872 & 0.0456 \\
Likelihood ratio & $13.19 * * *$ & & \\
\hline
\end{tabular}

*: Significant at $10 \%$ significance level; $* *$ : Significant at 5\% significance level; $* * *$ : Significant at $1 \%$ significance level; ${ }^{1}$ : Dealing with an agricultural activity apart from beekeeping (1: yes; 0: no); ${ }^{2}$ : Migratory beekeeping (1: yes; 0 : no).

Land size affected the economic efficiency positively $(\mathrm{P}=0.0549)$. It was concluded that the beekeepers hired the agricultural areas rather than farming. This can be explained that by hiring the agricultural areas, they could obtain additional income and they could transfer this income to beekeeping activity.

Income per hive affected the economic efficiency positively ( $\mathrm{P}=0.0002)$. As the income per hive increased, economic efficiency increased. The economic analysis results were in this way.

Dealing with and agricultural activity apart from beeping affected the economic efficiency negatively $(\mathrm{P}=0.0963)$. As the producers performed an agricultural activity apart from beekeeping, they could not spare enough time and interest to beekeeping and consequently this case had a negative effect on economic efficiency.

Honeycomb changing frequency affected the economic efficiency positively $(\mathrm{P}=0.0456)$. As the honeycomb changing frequency increased, the quality and the amount of the yield increased and accordingly, this case caused the increase of the income and consequently, the economic efficiency (Table 12).

\section{Discussion and Conclusion}

In this study, expenses, costs and profitability of beekeepers in honey production period in 2018 in Çanakkale Province were determined. Average honey yield per hive was found as $16.24 \mathrm{~kg}$ and this value is over the average yield value $(14.6 \mathrm{~kg})$ of Turkey.

Honey yield per hive was found as $12.32 \mathrm{~kg}$ in Mediterranean Region (26) and $19.27 \mathrm{~kg}$ in İzmir Province (23). As the production amounts of other bee products (royal jelly, beeswax, pollen, and bee gum) are little, it can be said that increasing the production of these products is necessary for the profitability of the enterprise.
The ratio of the fixed costs in the first group was higher than second and third groups. If the ratio of the variable costs is high, this means that the enterprises operate more intensive (4). From this point of view, it can be said that the enterprises in the third group operated more intensive. The ratio of family labor fee is higher than temporary labor expenses and this can be commented that the producers mostly maintain the beekeeping activity based on the family labor.

It was determined that fuel-transport and feed (sugar) costs had the highest share in the variable costs. Similar results were obtained from the study conducted in Adana (24). Low interest loan can be provided for the inputs used in the transport for arriving to the places for honey production and used in the feeding which is done in order to strengthen the colony in certain times of the production period, especially in spring, in migratory beekeeping. It can be applied low prices in sugar purchasing to the beekeepers who are the members of the unions or the cooperatives. Besides, bee accommodation areas and flora intensity should be determined contemporarily and rearranged for increasing the yield. The producers should be encouraged for insurance in order to reduce the effects of negative climate conditions and increase of insurance premium ratio should be provided by the government. The subsidy amount per hive should be increased and support of the inputs such as beeswax, bee cake should be provided. The cooperation of the related organizations in the region should be provided in order to give practical technical training to the producers on the subject of beekeeping and health protection.

As the scale of the enterprise increased, the cost of one $\mathrm{kg}$ of honey decreased in this study. Similarly, in previous studies conducted in Adana (24), Mediterranean Region (26) and Gökçeada (25) and Aegean Region (12), it was stated that the cost of one $\mathrm{kg}$ of honey decreased as 
the number of hive increased. It was obviously seen that the cost of $1 \mathrm{~kg}$ honey decreased according to the increase of the number of the hives. It was concluded that the hive number had a significant effect on honey production cost. The necessary supports should be provided to the producers in order to increase the number of the hives.

Technical efficiency, allocative efficiency and economic efficiency were determined as $0.89,0.74$ and 0.66 , respectively. The average pure technical efficiency values were found as 0.55 in Nigeria (2), 0.85 in Adana (24), 0.66 in Greece (22), 0.89 in Gana (1), 0.84 in Turkey (9) and 0.57 in Niğde (17). The technical efficiency coefficient of this study was the same as the result of the study conducted in Gana (1). In the study conducted in Turkey (9), the average allocative efficiency and economic efficiency of the beekeeping enterprises in Turkey were found as 0.75 and 0.62 .

The number of the completely efficient enterprises; in other words, the technical efficiency values were 1, was determined as 40 . In the study carried out in the Rocky Mountain region in the USA, it was determined that $25 \%$ of the enterprises were technically efficient (28). The number of the enterprises, which were fully economically efficient, in other words the economic efficiency values of which were 1 , was determined as 13 .

Technical efficiency scores were found to be higher than the economic efficiency scores. This result indicated that the producers required information on the subject of selecting suitable input combination on data price level rather than the technical information. It was determined that the effect of honeycomb changing frequency on economic efficiency was positive. The awareness of the producers should be raised on the necessity of honeycomb changing and hive control for honey production performance, honeycomb changing and hive control should be provided in appropriate frequency.

Economic and efficiency analysis results indicated that the relative profits and efficiencies of the enterprises in the third group were higher than the other groups.

The most important problems which the beekeepers encountered in beekeeping activity were marketing of the crops, struggling with diseases, accommodation areas, transportation and organization. The beekeeping unions should be more efficient for the solution of the problems in beekeeping sector. The beekeeping unions should be more active for the marketing of honey and other honey products. The determination of the locations of the hives will be useful for the solution of the accommodation area problem. The accommodation areas should be determined according to the floristic variety for the solution of the problems which the migratory beekeepers. It was concluded that illness and wintering losses affected the honey production. The employment of expert veterinarians should be provided in public establishments and unions for the recognition and treatment of the illnesses.

\section{Conflict of Interest}

The authors declared that there is no conflict of interest.

\section{References}

1. Abdul-Malik A, Mohammed A (2012): Technical efficiency of beekeeping farmers in Tolon-Kumbungu district of Northern region of Ghana. J Dev Agric Econ, 4, 304-310.

2. Aburime IL, Omotosho OA, Ibrahim H (2006): An analysis of technical efficiency of beekeeping farms in Oyo State, Nigeria. Eur J Soc Sci, 4, 1-8.

3. Açıl F (1977): Calculation of Agricultural Crop Costs and Developments in Agricultural Crop Costs of Our Country. Ankara University Faculty of Agriculture Publications, Edition No: 665, Scientific Research and Examinations: 91, Ankara.

4. Açıl AF, Demirci R (1984): Agricultural Economics Subjects. Ankara University, Agricultural Faculty Editions, Edition No: 880, Ankara.

5. Anonymous (2018): Beekeeping. Agricultural Economic and Policy Development Institute, Edition No: 26, Ankara.

6. Anonymous (2019): Çanakkale agriculture and livestock investment guide. South Marmara development agency, Çanakkale. Available

at https://www.gmka.gov.tr/dokumanlar/yayinlar/CanakkaleTarim-Hayvancilik-Rehberi.pdf. (Accessed May 15, 2019).

7. Aras A (1988): Agriculture Accounting. Ege University Faculty of Agriculture Publications, Edition No: 486, İzmir.

8. Borum AE (2017): A study of beekeeping survey in Southern Marmara region of Turkey. U Bee J, 17, 24-34.

9. Ceyhan V, Yeninar H, Demiryürek K, et al (2016): Economic Structure of Turkish Beekeeping Industry and Efficiency Analysis. TUBITAK Project No: 1130541, Samsun.

10. Charnes A, Cooper WW, Rhodes E (1978): Measuring the efficiency of decision making units. Eur J Oper Res, 2, 429444.

11. Coelli T, Rao DSP, Battese GE (1998): An Introduction to Efficiency and Productivity Analysis. Kluwer Academic Publishers, Boston.

12. Çevrimli MB, Sakarya E (2019): Economic analysis of beekeeping enterprises in Aegean region, Turkey. Ankara Univ Vet Fak Derg, 66, 109-115.

13. Çiçek A, Erkan O (1996): Research and Sampling Methods in Agricultural Economics. Gaziosmanpaşa University, Agricultural Faculty Publications No: 12, Tokat.

14. FAO (2018): Food and Agriculture Organization. Available at http://www.fao.org. (Accessed April 20, 2019).

15. Farrell MJ (1957): The measurement of productive efficiency. J R Stat Soc A, 120, 253-290.

16. Gujarati D (1999): Basic Econometrics. Translator: Ümit Şenesen, Gülay Günlük. Literature Publishing, İstanbul.

17. Gürer B, Akyol E (2018): An empirical analysis of technical efficiency determinants in beekeeping farms: 
evidence and policy implications from Niğde Province, Turkey. JAEID, 112, 343-359.

18. Ilgar R (2018): Beekeeping activities in Çanakkale Province. J Turk Stud, 13, 713-724.

19. Keskin G, Dellal İ (2011): Gross margin analysis for dairy cattle in Trakya Region. Kafkas Univ Vet Fak Derg, 17, 177-182.

20. Kıral T, Kasnakoğlu H, Tatlıdil FF, et al (1999): Cost Calculation Methodology for Agricultural Crops and Database Guide. Project Report 1999-13, Edition No: 37, Ankara.

21. Köseoğlu M, Yücel B, Saner G, et al (2008): Current situation analysis of Turkey beekeeping. Hasad Hayvancilik, 281, 52-61.

22. Makri P, Papanagiotou P, Papanagiotou E (2015): Efficiency and economic analysis of Greek beekeeping farms. Bulg J Agric Sci, 21, 479-484.

23. Onuç Z, Yanar A, Saner G, et al (2019): An analysis of economical aspect of the beekeeping enterprise: a case of Kemalpaşa district-İzmir/Turkey. Ege Univ Ziraat Fak Derg, 56, 7-17.

24. Ören N, Alemdar T, Parlakay O, et al (2010): Economic Analysis of Beekeeping Activity in Adana Province. Agricultural Economics Research Institute Edition No: 78, Ankara.

25. Özsayın D, Karaman S (2018): Determination of honey production costs in beekeeping enterprises. 592-598. In: II.
International Scientific and Vocational Studies Congress Proceedings Book, 05-08 July 2018, Nevşehir, Turkey.

26. Öztürk C, Subaşı OS, Uysal O, et al (2014): Determination of Technical and Economical Structures of Beekeeping Enterprises in the Mediterranean Region. Agricultural Economic and Policy Development Institute, Edition No: 254, Ankara.

27. Parlakay O, Yılmaz H, Yaşar B, et al (2008): The situation of beekeeping in Turkey and the future expectations by the trend analysis method. Uludag Üniv Ziraat Fak Derg, 22, 17-24.

28. Ritten CJ, Peck D, Ehmke M, et al (2018): Firm efficiency and returns-to-scale in the honey bee pollination services industry. J Econ Entomol, 111, 1014-1022.

29. Sancak K, Zan Sancak A, Aygören E (2013): Beekeeping in the World and Turkey. Arıcılık Araştırma Derg, 10, 7-13.

30. Tarım A (2001): Data envelopment analysis: Mathematical based relative efficiency measurement approach. Ankara University SBF Journal, 56, 191-193.

31. TUIK (2018): Statistical Indicators. Available at http://www.tuik.gov.tr. (Accessed April 30, 2019).

32. Yamane T (1967): Elementary Sampling Theory, PrenticeHall Inc., Englewood Cliffs, New Jersey.

33. Zaim O (1999): Applied Economics. Unpublished Lecture Notes, Bilkent University, Faculty of Economics and Administrative Sciences, Department of Economics, Ankara. 